\title{
Voltando ao tema: tréplica
}

\section{Returning to the theme: a new reply}

\section{Solon Magalhães Vianna}

Odontólogo e Sanitarista, Livre Docente em Saúde Pública. ExPesquisador do Instituto de Pesquisa Econômica Aplicada - IPEA. Consultor

E-mail: solonळyawl.com.br
Reli, por dever de ofício, não por prazer, o artigo escrito em 1991 e o produto, mais recente, de sua re-visita, datado de março de 2004. Em geral não gosto de reler o que escrevi no passado, mas isso não tem nada a ver com o aforismo atribuído ao ex-presidente FHC (esqueçam o que escrevi).

Prazer tive na leitura dos judiciosos comentários de Eduardo Jorge, sobretudo por constatar que, defendendo a mesma causa, estamos de acordo no essencial e na mesma luta. Cada um a seu modo e estilo e, eventualmente, em arenas diferentes. E mesmo onde pareceria haver discordância, o que há, de minha parte, é certo ceticismo ou preocupação com o sucesso de algumas estratégias no processo de construção do Sistema Único de Saúde - SUS. Refiro-me especificamente a algumas das questões apontadas por Eduardo Jorge, como o papel do PSF, a criação do Ministério da Seguridade Social - MSS e o financiamento do SUS.

Reconheço a necessidade de o PSF contar, como lembrado, com 80 mil equipes, e a importância estratégica desse Programa. Inúmeros fatores contribuem para a viabilidade dessa meta de expansão. Entre os fatores favoráveis destaco a abundante oferta de recursos humanos, particularmente no que se refere a médicos, e a prioridade que essa política pública tem recebido desde os anos noventa, não só no Ministério da Saúde - MS como em instâncias locais.

Resta, ainda, muito por fazer. Por exemplo, na melhoria do ensino médico e na capacitação dos quadros existentes, sem o que as equipes não exercerão integralmente suas potencialidades no que se refere à resolutividade. Mas não basta que as equipes sejam capazes de dar solução à maioria dos problemas de saúde. É necessário também que os casos não tratáveis no nível primário de atenção tenham acesso agendado pelo próprio Programa - à atenção secundária e à de alta complexidade. Isso requer articulação permanente do PSF com os demais níveis, mediante esquemas apropriados de referência e contra-referência. Neste último aspecto parece que ainda não chegou a hora de comemorar. 
Recursos financeiros crescentes, pelo menos na área federal, têm propiciado a ampliação do Programa. Contudo, é fundamental também impedir a deterioração dos salários, primeiro passo para a queda de qualidade dos serviços. Entendo até que, se for necessário, será preferível diminuir o ritmo de expansão do que deixar que perdas salariais contaminem o moral do Programa. Edital recente de concurso de uma Secretaria de Saúde oferece a um médico com carga horária de 20 horas semanais remuneração correspondente a mais da metade do que o PSF prevê para um profissional de 40 horas. Ora, para ser atraente e propiciar uma seleção mais rigorosa, o pagamento do médico de família deveria corresponder, no mínimo, ao dobro do que é pago aos demais, dadas a diferença de carga horária e as peculiaridades do Programa.

De qualquer forma, não me agrada o regime de trabalho de 40 horas sem dedicação exclusiva, como acontece no PSF. Há claros sinais, tanto na área de educação como na saúde, de que a possibilidade de outra(s) ocupação(ões) (plantões, consultório privado) pode(m), a médio e longo prazos, transformar o Programa Saúde da Família em mais uma atividade entre as inúmeras exercidas pelo médico brasileiro. Esse risco cresce quanto mais o salário perde poder de compra ao longo do tempo. Por que então não exigir dedicação exclusiva como contrapartida de salário minimamente atrativo? Instituições que construíram uma imagem positiva, como a Fundação SESP, no passado, e a Rede Sarah, no presente, devem seu prestígio em grande medida à adoção desse regime de trabalho.

Outro ponto defendido por Eduardo Jorge é a criação do Ministério da Seguridade Social. Penso que perdemos, não necessariamente em definitivo, a oportunidade de experimentar a integração organizacional das três áreas que compõem a seguridade social, como no modelo inglês. Não subestimo as vantagens dessa unificação. Entretanto não valorizaria em demasia o enxugamento da máquina, pois este depende de mudança profunda no entendimento sobre o que deve ser um sistema de saúde descentralizado em um país federativo, diversificado e de grande dimensão territorial.

0 processo de descentralização, quase 15 anos depois de seu início, não reduziu o tamanho do Ministério da Saúde. Por um lado, por força do excessivo poder de controle e regulação exercido pelo Ministério da Saúde sobre estados e municípios. Por outro, pela permanência no âmbito federal de uma pesada estrutura de prestação de serviços médico-hospitalares de natureza local ou regional, ainda que operada por organizações com diferentes graus de autonomia: a Rede Sarah, presente em algumas capitais, e o Grupo Hospitalar Conceição em Porto Alegre são os exemplos mais notórios. Essa situação peculiar resulta da sinergia entre dois fatores: o interesse federal em preservar o status quo e a aparente inapetência estadual e/ ou municipal para assumir novos encargos, ainda que seus de direito.

Continuo acreditando que ministérios grandes não são, só por essa característica, ministérios fortes. A robustez política não é dada somente pela magnitude orçamentária e autonomia financeira, como acontece na previdência social, que jamais perdeu o controle sobre a arrecadação da principal contribuição social (contribuição de empregados e empregadores). Depende também do patrimônio político, como mencionei no segundo artigo, e da personalidade de seu titular.

Como diz o velho adágio, é o homem que faz o cargo e não o cargo que faz o homem. Delfim Netto comandou a economia tanto apoiado na enorme burocracia fazendária como Ministro da Fazenda (Governo Médice), quanto como Ministro do Planejamento (Governo Figueiredo), quando operava uma estrutura organizacional mínima. Os militares nunca foram politicamente tão frágeis na nossa história republicana como a partir da criação do Ministério da Defesa no governo FHC, megaestrutura resultante da integração sob comando único (até agora civil) das três forças singulares. Se a integração foi ruim para o status das Forças Armadas não importa. Neste caso, o que conta é ter sido, sem dúvida, ótima para a democracia.

Acredito também que o futuro do Sistema Único de Saúde - SUS - depende muito mais de um outro fator: saúde como política de Estado, o que asseguraria à saúde, se não prioridade absoluta, pelo menos sustentabilidade e maior imunidade às restrições fiscais. Políticas públicas como meras políticas de governo têm mostrado no Brasil baixa resistência à alternância no poder. Mesmo assim, o SUS parece ser o mais próximo a que se chegou de uma política de Estado. Ainda que a insuficiência do seu financiamento seja uma constante, seus princípios e diretrizes permanecem inalterados e se evidenciam como consensuais entre as diferentes correntes políticas e ideológicas. 
Falta porém pressão adequada da sociedade em sua defesa. Foi a pressão social que blindou o sistema de saúde inglês, modelo que inspirou o SUS, contra as tentativas de sucateamento perpetradas durante o longo governo conservador da primeira-ministra Sra Margareth Thatcher. Já no Brasil a classe média, justo o segmento com maior capacidade de vocalização de interesses -, por preconceito ou elitismo, preferiu migrar para os planos de saúde aos primeiros indícios de perdas qualitativas no sistema público. Não foi diferente na educação. Esse desapreço da classe média e das elites pelos serviços públicos, - excetuadas algumas ilhas de excelência demandadas pelos incluídos de sempre - reforça as desigualdades e realimenta a perda de qualidade.

Na verdade, o SUS, afora nos bens públicos de prestação não-individualizada (vigilâncias sanitária e epidemiológica) que provê, só alcançou universalidade nas duas pontas do sistema: no mais simples e barato, - as campanhas de vacinação, por exemplo - e no mais complexo e caro, não provido pelos planos de saúde, como os transplantes, a hemodiálise e os chamados medicamentos excepcionais, inacessíveis inclusive para a maior parte dos que estão no topo da pirâmide de renda. Daí por que - como mostra estudo do IPEA em andamento -, enquanto todo o gasto federal com ações e serviços de saúde entre 1995 e 2003 cresceu, em valores correntes, $122 \%$, a despesa com atenção de alta complexidade aumentou $225 \%$.

Por fim, lembro que o avanço no financiamento do
SUS a partir da EC n. ${ }^{0} 29$ teria sido mais expressivo se a Emenda estivesse sendo cumprida por todos os entes federados. Como aponta Eduardo Jorge, alguns estados, curiosamente os mais ricos, "continuam fora da lei". Falta também (i) adotar o repasse automático para estados e municípios, reduzindo ao mínimo as transferências voluntárias; (ii) garantir a eqüidade alocativa mediante critérios transparentes, de modo que estados e municípios mais pobres recebam um valor per capita mais alto que os demais. Estudo da Fiocruz de 2001, coordenado por Sílvia Marta Porto, mostra como fazêlo. A proposta, entretanto, feita por encomenda do Ministério da Saúde, permanece fora da agenda política, para surpresa e/ou decepção dos atores comprometidos com a descentralização e a eqüidade.

Enquanto a sociedade brasileira não desatar esses nós, dificilmente deixará de conviver com o paradoxo de o Brasil ser o único país do mundo com sistema de saúde de acesso universal onde (i) o gasto privado com saúde é maior que o gasto público, (ii) prosperam sistemas fechados de atenção privada financiados com recursos públicos, embora a Constituição tenha criado um sistema único (sic) e (iii) os segmentos mais afluentes desfrutam de incentivos fiscais para atender serviços de saúde diferenciados. A identificação desses contra-sensos e de outros obstáculos à consolidação do SUS, mencionados no texto inicial e nas oportunas e pertinentes observações de Eduardo Jorge, longe de desanimar, devem servir de estímulo para não esmorecer na luta. 